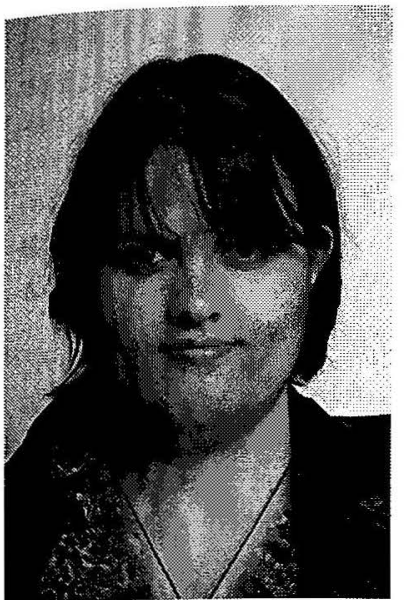

\title{
TURNING THE GAZE: LET'S TALK TO THE WORKERS
}

\author{
Keitha Small and Vera Keefe-Ormsby
}

\author{
Te Röpü Rangahau Hauora a Eru \\ Pömare \\ Wellington School of Medicine and \\ Health Sciences
}

\begin{abstract}
This paper discusses a research project that was undertaken to explore workers' experiences about their work-related injury and illness. We adopted a Kaupapa Mäori approach for the fieldwork and the analysis. A number of Mäori in the labour market have had different experiences from non-Mäori, in particular Mäori women. Since the 1984 Rogernomics era, workers have had to tolerate structural and political changes that have not benefited the majority of New Zealanders, especially tangata whenua. This research provided a "voice" for workers to share their stories and experiences in their work-places.
\end{abstract}

\section{Introduction}

During the post World War Two period of New Zealand, employment in the $1950 \mathrm{~s}$ and $60 \mathrm{~s}$ was based upon economic and social policies that regulated and protected the country's manufacturing and service sector (The Prime Ministerial Task Force on Unemployment, 1994). New Zealand's wealth at the time came from agriculture, especially by exporting to the United Kingdom. It was also during this period that Mäori labour market participation was higher than non-Mäori labour market participation (Statistics New Zealand, 1994).

However Mäori and Pacific Islanders were systematically excluded from professional employment and were predominately employed in occupations that required unskilled or semiskilled labour (Ongley, 1991).

With the 1984 election of the fourth Labour Government, New Zealand began to restructure the economy towards reducing inflation by creating an internationally competitive economy. In terms of employment, the consequence of a restructured economy was the impact of low wages and the 'shedding' of workers when times became difficult for organisations (Kelsey, 1995).

The impact of these reforms on Mäori was staggering. The trend with non-Mäori in regards to labour market participation began to shift and since 1986 Mäori participation began to fall (The Prime Ministerial Task Force on Unemployment, 1994).
Consequently during this period there was an increase in unemployment for Mäori compared to non-Mäori especially over a long period of time (Te Puni Kokiri, 1998a).

The changes that have occurred both economically and industrially has streamlined Mäori towards certain industries $^{1}$ where they are more exposed to work-place deaths (McCracken et al., 2001) or requiring ACC assistance for work related injuries (Te Puni Kokiri, 1998b).

\section{Background to research}

There has been little research carried out either nationally or internationally that looks at the influence of work site rules and the policy context on the way in which workers respond to signs and symptoms of illness and injury. The way in which workers respond is likely to have a profound influence on their experiences of illness and injury. The longer that symptoms are ignored can lead to a worsening of a particular condition. Conversely, promotion of early recognition may encourage oversensitive responses to symptoms. The purpose of the research was to explore the topic of workers' perceptions of, and responses to, the informal and formal rules surrounding workplace risk-taking activities, the reporting of illness, and the seeking of accident

\footnotetext{
${ }^{1}$ Such industries where there is an increase in fatalities and injuries are mining, manufacturing, electricity, gas and water supply, transport and storage; and construction.
} 
compensation for injury. The objectives to test the hypotheses were:

- Social pressures and formal rules in the workplace influence workers in ways which have long-term detrimental consequences for their health;

- The impact of these rules and social pressures affect Mäori and non-Mäori in distinctly different ways;

- That different work tasks such as clerical work and labouring are associated with different types of pressures;

- That the ability of workers to control the work process influences the ways in which they respond to signs and symptoms of injury and illness.

This paper provides a preliminary finding of the study and discusses the Kaupapa Mäori methodology that positioned our research into an arena where we critique the structural systems of society. Such systems include economic, political, ethnic, legal, medical and organisational factors.

\section{Research Process}

\section{Kaupapa Mäori Methodology}

Kaupapa Mäori research attempts to retrieve space for Mäori voices and realities whereby Mäori realities are seen as legitimate. Graham Smith (1990) notes that Kaupapa Mäori research:

- $\quad$ is related to "being” Mäori;

- $\quad$ is connected to Mäori philosophy and principles;

- takes for granted the validity and legitimacy of Mäori, the importance of Mäori language and culture; and,

- $\quad$ is concerned with the "struggle for autonomy over our own cultural well being."

Moana Jackson (1996) points out "research should be a liberating exercise and we can only do that if it is within a process we can control, and what we think research is all about". Also intrinsic to both the study and Kaupapa Mäori is an analysis of existing power structures and societal inequalities (Pihama, 1993).

Therefore as Mäori health researchers our position on Kaupapa Mäori methodology will critique Päkehä constructions and affirm the importance of Mäori selfdefinitions and self-valuations (Collins, 1991; Pihama, 1993). This means taking for granted the importance of Mäori language and culture, philosophy and principles, and striving for tino rangatiratanga (Smith, 1996). These then become the common sense; instead of being seen as 'other' and lacking in 'mainstream' legitimacy (WaiparaPanapa, 1995).

A qualitative methodology was mooted initially with methods of interviewing sixteen focus groups at a minimum of four different workplaces.

Focus groups are a method of choice in exploratory research where little is known about the possible responses and the aim is to ascertain respondents' knowledge and experiences, and to explore why respondents think in the way they do. Focus groups enable respondents to explore and clarify their views in relations to the group (Kitzinger, 1995).

The selection of focus groups was to be based on a theoretical sampling model where the participants are selected to reflect a range of the population. It is possible that those in office-based work may have different responses from those doing more physical or factorybased work, that Mäori may have different experiences from non-Mäori, and that worker control over the work process may affect the workplace experience. It is for these reasons that focus groups were to be arranged at different sites.

The initial selection for work sites were selected from a list supplied by Occupational Safety and Health (OSH) at the Department of Labour. The research team decided to focus on organisations that had 100 or more employees.

Organisations were contacted at first by telephone and were given initial information about the project. Further information was sent and organisations were followed up with a phone call to discuss if they wanted to participate in the study. All but one organisation declined to participate. The reasons for not wanting to participate were;

- The study did not fit in with current their human resource management programmes and training;

- Human resource managers did not want to ask their superiors for permission to conduct the study;

- The organisation did not have the time to incorporate this study into their work schedule; and

- They were not interested in the study.

We developed a process with the one site that agreed to participate. This involved meeting with management to decide what would be the most effective way to inform worker volunteers. To recruit volunteers we sent information out with an employee's payslip. However, through this process, we got a low response rate. 
Because of the lack of responsiveness from both organisations and participants within an organisation, we reviewed and critiqued our research process. One of the researchers had developed working relationships with a major industry and we utilised this relationship. In addition she had whänau who were union delegates, managers or workers at other work sites.

We undertook a Kaupapa Maori approach of utilising these whakapapa and whänau networks. Both these concepts are fundamental to being a member of whänau, hapu and iwi. The researcher approached her whänau at the other four work-sites and we are indebted to their support as they advocated, lobbied with management, recruited volunteers, provided appropriate information, organised the interviews and at times worked outside of their normal working hours to support this project.

Interviews were conducted at four work sites and one off site. Tapes were transcribed and returned to the workers for correction, the deletion of quotes, and additional notes.

For the analysis, themes were categorised by using Nudist Nvivo. The themes were analysed and reviewed by the research team. Based on a Kaupapa Mäori analysis, it was important that we critiqued social structures that have influenced New Zealand society and how it has adversely impacted on Mäori while privileging Päkehä. In addition we were mindful that we did not have a deficit thinking approach which is about 'blaming the victim'. It is a model founded on imputation, not documentation (Valencia, 1997p.x).

\section{Preliminary Finding}

While there were many key themes for this paper, we want to focus upon one particular reoccurring theme. Initially, we had labelled this theme as "internalising blame" where the workers have accepted and internalised blame for their actions and inactions that have led to their sickness and /or injury. This internalisation allows the corporate organisations, employers and the state to displace their liability for any blame of injury or illness that may have occurred at the work site.

For example, the Health \& Safety Act 1992 came into force to encourage employers and workers to assess the hazards in their particular work environment and take the necessary precautions against accidents and illness at the enterprise level (Department of Labour, undated). The Department of Labour would overview the enforcement of this Act.

However a critique of this Act was that workers would trade off "health and safety aspects of their employment to keep their jobs, and felt unable to ask for protective clothing, challenge unsafe conditions or take time off work, sick" (Kelsey, 1995, p.202). Additionally the government has decentralised the responsibility of health and safety to the enterprise level where the "market fails to allocate sufficient resources to accident prevention and this leads to socially unacceptable levels of work-related death, injury and illness" (Deeks et al., 1995, p.447).

At an organisational level, employers may undertake health and safety initiatives that may reduce injury and illness within the workplace. Such initiatives may include stress management programs, exercise routines, or other worker centred programs. Even though these programs may have value in themselves, it focuses attention towards the worker as if there is something wrong with them without critiquing the organisation practices (Williams \& Thorpe, 1992).

Other legislative example is the Employment Contracts Act 1991 (ECA). The ECA created an era that made compulsory unionism illegal, abolished centralised wage bargaining and focused on individual contracts (Maloney \& Savage, 1996). However within the ECA environment, it was warned that workers would trade off health and safety aspects of their employment in order to keep their jobs (Kelsey, 1995). Additionally workers were in an environment where they are exposed to high productivity demands that would incur higher stress and work-related accidents.

Maintaining our analysis at a structural level enabled us to critique the power relationships between employees, employers and the state.

Hence this approach guided our analysis to even re-name the theme from "internalising blame" which had a focus on the worker to "turning the gaze" which focused on organisational and structural issues.

For example, one worker mentioned that;

"I didn't ask [about the health and safety rules] cause it was just the fact of getting a job cause that's all I really wanted was a job, I didn't really worry about that stuff, it wasn't important at the time...I'm just all out for getting a job and doing something" (AU)

This worker was keen to get employment at a work-site located in a rural area that had high unemployment. She was fiercely independent and gaining this job was very important. When she was employed, reading the workplace conditions of employment was not her priority. Her focus was to do the work. She was a good employee, giving years of loyal service and persevering with many organisational changes that to a high degree even impacted on her personal life.

When she suffered a workplace accident she at least expected some support, even a user- friendly process that would assist her to recover and rehabilitate to get back into the workforce. What she found was contrary to her belief and she eventually realised that her employer had not demonstrated "good employer" work ethics and nor did they display any sense of loyalty to workers. Her engagement with ACC and the employer's rehabilitation process affected her opinion of the organisation and 
failed to address her rights as an employee as well as a participatory citizen in the labour market. She began to internalise blame partly because she felt that she did not know what her entitlements were in regards to health and safety within the workplace. Also she was not a union member but she found that the union delegate was to become her key advocate and support and this led her to become politically aware about her entitlements within the workplace. This also became the springboard for her to become an active union member.

The effects of the ECA had discouraged workers from affiliating to the union and it appears that a number of them became active after experiencing such events.

Another worker described and critiqued the work environment he worked in as:

"you're like the mickey, you know, run over there, and the jobs I normally work on are usually the jobs they take people away from. So they're always like short a man, so you've got to do extra job between four of us instead of five ... and they can take two away from there and still leave the chain running at $8 / 3$, you know, it's hard"(I)

This worker had experienced several workplace injuries. A key factor was the type of work he engaged in which was repetitive and involved using a sharp knife.

Another factor was the design of the workplace. The cutting tables were at a height that meant he had to often bend and this eventually affected his back and legs. The proximity of the worker next to him meant he had a limited workspace to perform his tasks as well as ensuring that he did not endanger other neighbouring workers. Hygiene regulations imposed conditions that made the work environment unsafe in that the floor was usually rather slippery and greasy.

Workers would also recognise other environmental and organisational that would impact on them. Other workers, particularly Mäori women recognised their being "injured" within the workplace by racist and sexist behaviour and practices. One work-site has had many structural changes over the last twenty years and this involved introducing women into that arena. However, it is evident that the workplace remains a bastion for males. Mäori women workers within a specific department were subjected to racist and sexist comments from a work place supervisor.

"we get a supervisor who stands over you and starts yelling and screaming at you to hurry up. That if my Päkehä girls were here they could do this'. That's just what he does to us. And so we just carry on with our work. He calls us black bitches, abbos's" (LU)

This type of behaviour is intolerable and contravenes both human rights and health and safety legislation. Also this is about the abuse of power as a supervisor. The women felt that there were no "safe" processes for them within the department at the work-site. Although they spoke to a female union delegate and she advocated on their behalf, this only intermittently changed the behaviour of the supervisor. The women felt that if they took the matter to the employer their stories would not be credible and other supervisors and work colleagues would harass them.

However, employers are required to provide a safe work environment and that goes beyond organisational design. It includes protection against sexual harassment and practices of both racism and sexism. This worker felt that due to racism and sexism they often overlooked safety in the workplace to "get the work" done and be accepted within the workplace. Within that some of the women became physically and emotionally injured that then led them onto experiencing other forms of abuse by the system such as barriers to claiming ACC or taking sick leave.

It was also noted that racism was experienced in other work-places i.e. a health service delivery industry, where racism was presented by not recognising to contribution of Mäori workers;

"I think that the biggest racist issues is not enough recognition of values and the way that people do things when you're in a [health service delivery industry] ... and that can be stressful and have a bearing on our wellbeing, cause we have to explain to the [non-Mäori] staff why we need to do it this way rather than that way, and you can constantly be explaining things..." (CC)

Again within this organisation, racism was carried out where Päkehä workers were privileged into higher positions over Mäori workers;

"there's always been institutional racism, it was the same in ..., all the hard workers there were Mäori and they didn't really get the high positions not only there but here as well, lots of intelligent workers, but that's the way it goes, they're working to look after their own and I think it sort of will always be like that. Racism will always be like that, it's the way they are [management]" (CCM)

These quotes highlight that racism whether overt and/or covert impacts on the wellbeing of Mäori by privileging non-Mäori as being the "norm". This attitude enabled non-Mäori to set the standards for work behaviour, that so often included the maintenance or emergence of racist practices and behaviour that had an effect on the health and wellbeing of Mäori workers within the work environment.

\section{Conclusion}

The aim of this project was to raise awareness of health and safety issues for Mäori who are employed in manufacturing and service delivery environments. The key theme of "turning the gaze" is important because it 
gives power to the voice of workers who are often powerless within their work environments that led them to internalising blame for their illness and injury. Over the years legislation and policies like the ECA have been developed to protect employers and not employees. The 1984 economic restructuring has left a legacy of workers, especially Mäori, accepting jobs that are poorly remunerated and work conditions that are unsafe.

A number of workers mentioned that they accept the work conditions and poor remuneration because they prefer that rather than "not" working. The debunking of the myth that people "do not want to work" needs to be eliminated by the media and politicians.

While this study is explorative, it does open challenges to New Zealand society who must take responsibility for endorsing policies, practices and legislation that have done more harm than good for the majority of people, especially tangata whenua.

\section{Future Research}

As mentioned in the previous section, this research is still being developed. However there is room for further research in health and safety at work arena. Research into the adverse impact of economic and social policy on Mäori should be critiqued. One option would be further study in who has "benefited" and "not benefited" from social and economic policies.

Note: We wish to thank the whänau, unions, management and participants for supporting this project.

\section{References}

Collins, P.H. (1991). 'Learning from the outsider within', in Fonow, M. and Cook, J.A. (eds.), Beyound Methodology: Feminist Scholorships as lived research, Bloomington: Indiana University Press.

Deeks, J., Parker, J. and Ryan, R. (1995). Labour and employment relations in New Zealand, Auckland: Longman Paul.

Department of Labour (undated). A guide to managing health and safety, Auckland: Department of Labour.

Jackson, M. (1996). 'Maori health research and Te Tiriti o Waitangi', Hui Whakapiripiri: A hui to discuss strategic directions for Maori health research, $\mathrm{Te}$ Pumanawa Hauora ki Te Whanganui a Tara.

Kelsey, J. (1995). The New Zealand experiment; $A$ world model for structural adjustment?, Auckland: Auckland University Press with Bridget Williams Books.
Kitzinger, J. (1995). 'Qualitative Research - Introducing Focus Groups', British Medical Journal, 311, 7000, 299-302.

Maloney, T. and Savage, J. (1996). Labour markets and policy, Wellington: Elservier Science B.V.

McCracken, S., Feyer, A.M., Langley, J., Broughton, J. and Sporle, A. (2001). 'Mäori work-related fatal injury, 1985-1994', New Zealand Medical Journal, 114, 1139, 395-399.

Ongley, P. (1991). 'Pacific Islands' migration and the New Zealand labour market', in Spoonley, P., Pearson, D. and Macpherson, C. (eds.), Nga Take; Ethnic relations and racism in Aotearoa/New Zealand, Palmerston North: The Dunmore Press.

Pihama, L. (1993). 'Tungia te Ururua, Kia Tupu Whakaritorito te Kupe o te Harakeke: A critical analysis of parents as first teachers', Auckland: University of Auckland.

Smith, G.H. (1990). 'Research issues related to Mäori education', NZARE Special interest conference, Massey University: University of Auckland.

Smith, L.T. (1996). 'Kaupapa Mäori health research', hui Whakapiripiri: $A$ hui to discuss strategic directions for Mäori health research, Wellington School of Medicine: Te Ropu Rangahau Hauora a Eru Pomare.

Statistics New Zealand (1994). 'Work', New Zealand Now. Mäori, Wellington: Statistics New Zealand.

Te Puni Kokiri (1998a). 'Progress towards closing social and economic gaps between Mäori and nonMäori; A report to the Minister of Mäori Affairs', Wellington: Te Puni Kokiri.

Te Puni Kokiri (1998b). 'Review of ACC. Service delivery to Mäori', Wellington: Te Puni Kokiri.

The Prime Ministerial Task Force on Unemployment (1994). 'The Changing Labour Market', Employment, the issues, Wellington: Government Print.

Valencia, R.R. (ed.) (1997). The evolution of deficit thinking; Educational thought and practice, London: The Falmer Press

Waipara-Panapa, A. (1995). 'Body and Soul; A socioculutral analysis of body image in Aotearoa', Auckland: University of Auckland.

Williams, C. and Thorpe, B. (1992). Beyond industrial sociology: The work of men and women, Sydney: Allen \& Unwin. 